\title{
Effect of Soil Water Deficit on Yield and Its Components at The Different Growth Stages in Rice (Oryza sativa)
}

\author{
S.H. Aboukhadrah, A. A. Abd Allah*, H. S. Gharib and \\ Raghda M. Sakran*** \\ Agronomy Dept., Fac. of Agriculture 33516, Kafrelsheikh University; \\ *Rice Research \& Training Center, Field Crops Research Institute, \\ Agriculture Research, Center, Sakha, Kafrelsheikh, Egypt and \\ ** Laboratory of Plant Cell Technology, Fac. of Applied Biological \\ Sciences, Gifu University, Gifu 501-1193, Japan.
}

$\mathbf{T}$

WENTY FIVE rice (Oryza sativa) genotypes were evaluated under normal (continues flooding) and drought (irrigation every 12 days) conditions at the experimental farm of the Rice Research and Training Center, Sakha, Kafrelsheikh, Egypt during 2011 and 2012 to study the genetic variability, phenotypic correlation as well as identify the desirable genotypes that could be used as donors in rice breeding program. Combined analysis of variance was performed for data collected on number of panicles plant ${ }^{-1}, 100$-grain weight (g), sterility percentage $(\%)$, grain yield plant ${ }^{-1}(\mathrm{~g})$, Harvest index $(\%)$ and water use efficiency (WUE) $\left(\mathrm{kg} / \mathrm{m}^{3}\right)$. Highly significant differences were observed among the genotypes for all studied traits. Genotype $\times$ Environment mean squares were highly significant for all the examined traits. The genotypes GZ 1368-S-5-4, Morobrekan, GZ 5121-5-2, WAB 878 and Goari were recorded the best performing entries under the drought conditions for grain yield plant ${ }^{-1}(\mathrm{~g})(31.38$, $30.98,29.73,28.99$ and $29.25 \mathrm{~g})$ and some of its related traits and could be used as donors to enhance such traits. Among the studied traits grain yield plant ${ }^{-1}(\mathrm{~g})$ and harvest index $(\%)$ had the highest genotypic and phenotypic variances. WUE recorded the lowest genotypic and phenotypic variances under both conditions. The phenotypic coefficient of variability $(\mathrm{PCV} \%)$ was higher than genotypic coefficient variability (GCV\%) under both normal and drought conditions for the all traits indicating the existence of wide genetic variability in these genotypes and that selection to improve such traits could be practiced effectively in the segregating populations after crossing among them. High estimating values of heritability were observed in all the examined traits under the normal and drought conditions except for harvest index under drought stress condition. Highly significant and positive correlation coefficient was determined between grain yield plant ${ }^{-1}$ and most of the yield attributes under the normal and drought conditions.

Keywords: Normal and drought conditions, Water deficit, Rice (Oryzas sativa), Grain yield, Yield components, Water stress, Heritability, Water use efficiency. 
Drought remains one of the most serious problems in agriculture, rice (Oryza sativa) as a submerged crop, is more susceptible to drought stress than other plant species. Shortage of irrigation water is one of the major obstacles for increasing rice production not only in Egypt, but also at the worldwide. According to statistical data, about $50 \%$ of the world rice production is affected more or less from the drought conditions (Bouman et al., 2005). In Egypt, rice crop is one of the major water consuming crops and continues flooding is the only method of irrigation. Rice covered area in Egypt 700000 ha (FAO, 2013). Some rice varieties cultivated areas which are located at the end of the irrigation canals in the northern part of the Nile Delta suffer from shortage of irrigation water that cause drought conditions at the different growth stages, which are considered to be one of the most serious constraints to rice production in Egypt (Abd Allah et al., 2009). Most of cultivated rice varieties are considered as drought sensitive crop varies with stage of growth (Abdel Hafez et al., 2013). Drought mainly influences grain yield by limiting seed numbers, by either influencing the amount of dry matter produced by the time of flowering or by directly influencing pollen or ovule function, which leads to decreased seed set. Secondly, drought influences seed filling mainly by limiting the assimilate supply, leading to smaller seed size and lower yields (Prasad et al., 2008). Drought stress near heading has been shown to reduce grain yield in rice cultivars by inhibiting processes such as anther dehiscence (Liu et al., 2006) and panicle exertion (Ji et al., 2005 and Pantuwan et al., 2002). Furthermore, water deficit also increases the formation of reactive oxygen species (ROS), resulting in lipid peroxidation, protein denaturation and nucleic acid damage with severe consequences affecting the overall metabolism (Hansen et al., 2006). All of these and these kind factors are responsible for the reduction of grain yield under the drought conditions. The main objective of this study was to identify tolerant genotypes to drought conditions depending on some traits associated with drought tolerance to use them as donors in the rice breeding program (s).

\section{Materials and Methods}

The present study was carried out at the experimental farm of Sakha Research Station, Kafrelsheikh, Egypt during the 2011 and 2012. Total, 25 genetically diversed rice (Oryza sativa) cultivars were used in this study. Seeds were obtained from the Rice Research and Training Center, Field Crops Research Institute, Agriculture Research Center, Egypt.

\section{Field experiments}

In 2011 and 2012, seeds of the each cultivar's were sown in the nursery, then they (seedlings) were transplanted into two adjacent experimental fields. The first one was normally irrigated (continuous flooding) and the second one drought was irrigated every 12 days. After thirty days from the sowing, seedlings of each genotype were individually transplanted into their permanent field(s) in seven rows. Each row was five meters long and contained 25 hills with one plant/hill. The soil of experiment was clay in texture containing 1.7-1.55 meq. $\mathrm{L}^{-1}$ of $\mathrm{N}, 14.8-14.02 \mathrm{ppm}$ for $\mathrm{P}, 15.50-14.80 \mathrm{meq} . \mathrm{L}^{-1}$ for $\mathrm{K}, 1.36-1.39 \%$ organic 
matter and the $\mathrm{pH}$ was $8.15-8.25$ as the mean of two seasons. Each experiment was designed in a randomized complete block design (RCBD) with three replications. Package of recommendation for rice growing was applied. Data were taken for these parameters: number of panicles plant ${ }^{-1}, 100$-grain weight $(\mathrm{g})$, sterility $(\%)$, grain yield plant $^{-1}(\mathrm{~g})$, harvest index $(\%)$ and water use efficiency (WUE) $\left(\mathrm{kg} / \mathrm{m}^{3}\right)$.

Yield (kg/ feddan)

Water use efficiency WUE= water consumpitive use $\left(\mathrm{m}^{3} /\right.$ feddan $)$

Statistical analysis

The obtained data were statistically analyzed for analysis of variance according to Gomez \& Gomez (1984) by using computer statistical software of MSTAT-C. Treatment means were compared by Duncan's Multiple Range Test (Duncan, 1955). The combined analysis was calculated over the two years and also, for the two environs (normal and drought conditions). Before the calculations of the combined experiments, the error variance of the experiments was tested for the homogeneity of variance as described by Bartlett (1937), the genetic parameters were computed according to formula suggested by Burton (1952) and Hansen et al. (1956), and the correlation coefficients between the traits were fixed using Pearson's correlation coefficients.

\section{Results and Discussion}

\section{Analysis of variance}

Combined analysis of variance for grain yield plant ${ }^{-1}(\mathrm{~g})$ and its components over the two years are presented in Table 1. Year's mean squares were found not significant for all the studied traits except for sterility percentages (\%). Environs' mean squares were obtained highly significant and this result is showing that the drought stress has significant effect on the all traits. Drought stress significantly decreased the mean values for all the evaluated traits except sterility percentages. Increased spikelet sterility of rice under water deficit condition at flowering stage has been reported by Liu et al. (2006) and Jongdee et al. (2002).

Genotypes mean squares were highly significant for all the studied. This indicates the existence of a high degree of genetic variability in the material to be exploited in breeding program, and that also reflected the broad ranges observed for each trait.

Significant differences for the number of panicles plant ${ }^{-1}$ were detected among genotypes at each environment to the GZ 1368-S-5-4, Giza 178 and Giza 182 were recorded the highest mean values $(21.37,21.05$ and 20.28) over all the environments for number of panicles plant ${ }^{-1}$ while the Sakha 103 and Giza 177 were gave the lowest mean values (15.44 and 15.72) in Table 1. 
TABLE 1. Means and combined analysis of variance for yield and its component characters over two years.

\begin{tabular}{|c|c|c|c|c|c|c|}
\hline Factor & $\begin{array}{c}\text { Number } \\
\text { of } \\
\text { panicles } \\
\text { plant }^{-1}\end{array}$ & $\begin{array}{c}\text { Sterility } \\
(\%)\end{array}$ & $\begin{array}{l}\text { 100- grain } \\
\text { weight }(\mathrm{g})\end{array}$ & $\begin{array}{c}\text { Grain } \\
\text { yield } \\
\text { plant }^{-1}(\mathrm{~g})\end{array}$ & $\begin{array}{c}\text { Harvest } \\
\text { index }(\%)\end{array}$ & $\begin{array}{c}\text { Water use } \\
\text { efficiency } \\
\left(\mathbf{k g} / \mathbf{m}^{3}\right)\end{array}$ \\
\hline \multicolumn{7}{|l|}{ Year (Y) } \\
\hline Season 2011 & 17.728 & $10.972 \mathrm{a}$ & 2.433 & 30.754 & 28.196 & 0.624 \\
\hline Season 2012 & 17.890 & $10.861 \mathrm{~b}$ & 2.432 & 30.825 & 28.345 & 0.625 \\
\hline F test & ns & $*$ & ns & ns & ns & $\mathrm{ns}$ \\
\hline \multicolumn{7}{|l|}{ Environment } \\
\hline Normal & $20.044 a$ & $7.920 \mathrm{~b}$ & $2.567 \mathrm{a}$ & $37.438 \mathrm{a}$ & $34.968 \mathrm{a}$ & $0.645 \mathrm{a}$ \\
\hline Drought & $15.573 b$ & $13.914 \mathrm{a}$ & $2.297 \mathrm{~b}$ & $24.141 b$ & $21.573 b$ & $0.604 \mathrm{~b}$ \\
\hline F test & $* *$ & $* *$ & $* *$ & $* *$ & $* *$ & $* *$ \\
\hline \multicolumn{7}{|l|}{ Genotype (G) } \\
\hline Giza 159 & $17.99 \mathrm{fg}$ & $12.18 \mathrm{~cd}$ & $2.36 \mathrm{efg}$ & $26.63 \mathrm{kl}$ & $26.99 \mathrm{~g}-\mathrm{k}$ & $0.56 \mathrm{ij}$ \\
\hline Giza 175 & $16.15 \mathrm{j}-\mathrm{m}$ & $12.07 \mathrm{~cd}$ & $2.17 \mathrm{ij}$ & $28.81 \mathrm{I}$ & $27.24 \mathrm{~g}-\mathrm{k}$ & $0.57 \mathrm{hij}$ \\
\hline Giza 176 & $16.03 \mathrm{j}-\mathrm{m}$ & $15.63 \mathrm{a}$ & $2.11 \mathrm{j}$ & $30.86 \mathrm{fgh}$ & $22.94 n$ & $0.61 \mathrm{dfg}$ \\
\hline Giza 177 & $15.721 \mathrm{~m}$ & $11.75 \mathrm{def}$ & $2.43 \mathrm{c}-\mathrm{f}$ & $30.95 \mathrm{fg}$ & $36.80 \mathrm{a}$ & $0.61 \mathrm{def}$ \\
\hline Giza 178 & $21.05 \mathrm{ab}$ & 9.321 & 2.28ghi & $36.62 \mathrm{a}$ & $30.68 \mathrm{~cd}$ & $0.74 \mathrm{a}$ \\
\hline Sakha 101 & $16.79 \mathrm{~h}-\mathrm{k}$ & $11.94 \mathrm{de}$ & $2.46 \mathrm{c}-\mathrm{f}$ & $33.04 \mathrm{c}$ & $26.78 \mathrm{i}-1$ & $0.65 \mathrm{bc}$ \\
\hline Sakha 102 & $16.69 \mathrm{i}-1$ & $11.27 \mathrm{efg}$ & $2.37 \mathrm{efg}$ & $30.85 \mathrm{fgh}$ & $30.35 \mathrm{de}$ & $0.61 \mathrm{def}$ \\
\hline Sakha 103 & $15.44 \mathrm{~m}$ & $13.24 b$ & $2.21 \mathrm{hij}$ & $32.08 \mathrm{cde}$ & $28.76 \mathrm{efg}$ & $0.64 \mathrm{~cd}$ \\
\hline Sakha 104 & $19.33 \mathrm{de}$ & $11.50 \mathrm{def}$ & $2.54 \mathrm{c}$ & $32.59 \mathrm{~cd}$ & $29.25 \mathrm{def}$ & $0.65 \mathrm{bc}$ \\
\hline GZ 1368-S-5-4 & $21.37 \mathrm{a}$ & $8.53 \mathrm{mn}$ & $2.42 \mathrm{c}-\mathrm{f}$ & $35.81 \mathrm{ab}$ & $27.85 \mathrm{f}-\mathrm{j}$ & $0.74 \mathrm{a}$ \\
\hline GZ 5121-5-2 & $19.82 \mathrm{~cd}$ & $9.121 \mathrm{~m}$ & $2.50 \mathrm{~cd}$ & $36.45 \mathrm{a}$ & $28.65 \mathrm{e}-\mathrm{h}$ & $0.74 a$ \\
\hline Giza 182 & $20.28 \mathrm{bc}$ & $11.23 \mathrm{fg}$ & $2.38 \mathrm{~d}-\mathrm{g}$ & $27.93 \mathrm{ij}$ & $24.45 \mathrm{mn}$ & $0.55 \mathrm{j}$ \\
\hline Agmi & $16.63 i-1$ & 9.191 & $2.36 \mathrm{efg}$ & $25.66 \mathrm{i}$ & $24.61 \mathrm{~m}$ & $0.52 \mathrm{k}$ \\
\hline Goari & $19.30 \mathrm{de}$ & $11.79 \mathrm{def}$ & $2.55 \mathrm{c}$ & $32.26 \mathrm{~cd}$ & $32.44 b$ & $0.67 \mathrm{~b}$ \\
\hline Nabatat Asmar & 17.46ghi & $12.13 \mathrm{~cd}$ & $2.44 c-f$ & $31.06 \mathrm{efg}$ & $26.68 \mathrm{jkl}$ & $0.61 \mathrm{def}$ \\
\hline IRAT 170 & $16.05 \mathrm{j}-\mathrm{m}$ & $10.75 \mathrm{gh}$ & $2.49 \mathrm{cde}$ & $26.4 \mathrm{kl}$ & $28.51 \mathrm{f}-\mathrm{i}$ & $0.55 \mathrm{jk}$ \\
\hline IRAT 112 & $15.91 \mathrm{klm}$ & $11.77 \mathrm{def}$ & $2.34 \mathrm{fgh}$ & $28.36 \mathrm{i}$ & $30.87 \mathrm{bcd}$ & $0.59 \mathrm{fgh}$ \\
\hline Milyang 93 & $15.91 \mathrm{klm}$ & 10.21hij & $2.25 \mathrm{ghi}$ & $28.23 \mathrm{i}$ & $32.09 \mathrm{bc}$ & $0.58 \mathrm{ghi}$ \\
\hline IET 1444 & $18.73 \mathrm{ef}$ & $9.50 \mathrm{kl}$ & $2.43 c-f$ & $31.85 \mathrm{def}$ & $25.151 \mathrm{~m}$ & $0.65 \mathrm{bc}$ \\
\hline Suweon 360 & $18.13 \mathrm{fg}$ & $10.29 \mathrm{hi}$ & $2.19 \mathrm{ij}$ & $30.27 \mathrm{gh}$ & $26.01 \mathrm{klm}$ & $0.62 \mathrm{de}$ \\
\hline Yun Len 4 & 16.95hij & $9.62 \mathrm{jkl}$ & $2.70 \mathrm{~b}$ & $27.14 \mathrm{jk}$ & $26.96 \mathrm{~h}-\mathrm{k}$ & $0.57 \mathrm{hij}$ \\
\hline WAB 878 & $19.57 \mathrm{cde}$ & $8.24 n$ & $2.80 \mathrm{~b}$ & $32.64 \mathrm{~cd}$ & $29.15 \mathrm{def}$ & $0.68 \mathrm{~b}$ \\
\hline Morobrekan & $18.11 \mathrm{fg}$ & $8.991 \mathrm{~m}$ & $3.17 \mathrm{a}$ & $35.22 \mathrm{~b}$ & $27.31 \mathrm{~g}-\mathrm{k}$ & $0.73 \mathrm{a}$ \\
\hline Suweon 349 & $18.18 f g$ & $9.97 \mathrm{ijk}$ & $2.33 \mathrm{fgh}$ & $29.8 \mathrm{~h}$ & $26.92 \mathrm{~h}-\mathrm{k}$ & $0.61 \mathrm{def}$ \\
\hline E. Yasmine & $17.64 \mathrm{gh}$ & $12.69 b c$ & $2.53 \mathrm{c}$ & $28.25 \mathrm{i}$ & 29.34def & $0.56 \mathrm{hij}$ \\
\hline F test & $* *$ & $* *$ & $* *$ & $* *$ & $* *$ & $* *$ \\
\hline \begin{tabular}{|l} 
Interaction \\
$\mathrm{G}^{*} \mathrm{Y}$
\end{tabular} & . & . & $* *$ & $* *$ & $*$ & $* *$ \\
\hline$G^{*} E^{*} Y$ & ns & $* *$ & $*$ & ns & ns & ns \\
\hline
\end{tabular}

${ }^{*}{ }^{* *} \quad$ and ns indicate $\mathrm{P}<0.05, \mathrm{P}<0.01$ and not significant, respectively. Means within the same column of each factor followed by a common letter are not significantly different at the $5 \%$ level, according to DMRT.

Egypt. J. Agron. 37, No. 1 (2015) 
The lowest sterility percentages were found in the WAB 878, GZ 1368-S-5-4 and Morobrekan, (8.24, 8.53 and 8.99) while it was higher in the Giza 176 and Sakha 103 (15.63 and 13.24). Similarly, Morobrekan, WAB 878 and Yun Len 4 had the maximum 100 grain weight $(13.7,2.80$ and 2.70).

On the other hand, the Giza 177, IRAT 112, Milyang 93 and Gaori were given the highest mean values for harvest index percentage comparing with other genotypes $(36.80,30.87,32.09$ and 32.44) in Table 1.

The highest grain yield plant $^{-1}$ was found in the Morobrekan, GZ 1368-S-5-4, GZ 5121-5-2 and Giza 178 with highest values ranged from 32.0 to $36.0 \mathrm{~g}$ while, the lowest grain yield plant $^{-1}$ were seen with the Agmi, IRAT170, Giza 159 and Yun Len 4 with the values ranged from 25.66 to $27.14 \mathrm{~g}$ in Table 1.

Concerning WUE, the genotypes Giza 178, Morobrekan, GZ 1368-S-5-4 and GZ 5121-5-2 were found the most efficient in water use with values ranged from 0.7 to $0.74 \mathrm{~kg} / \mathrm{m}^{3}$. While, the varieties Agmi and E. Yasmin was given the lowest mean values, ranged from 0.52 to $0.56 \mathrm{~kg} / \mathrm{m}^{3}$.

\section{Variation and interactions}

The interaction between genotype and environment was highly statistically significant for all the studied traits (Table 1). The tested genotypes varied from environment to the other and ranked differently from normal to stress conditions. This interaction genotype $\mathrm{x}$ year were significant for all of the investigated traits, while genotype $\mathrm{x}$ environment $\mathrm{x}$ year interactions were not found statistically significant except for 100-grain weight (g) and sterility percentage (\%) were significant, indicating that the performance of the genotypes in each environment will not be changed from year to year.

Table 2 shows that interaction between genotypes and environments had significant effect on number of panicles plant ${ }^{-1}$, sterility (\%) and 100-grain weight $(\mathrm{g})$.

Significant reduction in number of panicles plant ${ }^{-1}$ was observed under drought conditions compared with the non-stress conditions in the Giza 178, IET 1444 and GZ 1368-S-5-4 had the highest mean values under both normal and drought conditions except in the IET 1444 under the drought conditions while IRAT 170 under normal condition and Sakha 103 under drought conditions gave the lowest mean. These results were in agreement with those reported by Abd Allah (2010), Singh et al. (2010) and Krishnan et al. (2011). 
TABLE 2. Number of panicles plant ${ }^{-1}$, sterility (\%) and 100-grain weight (g) as affected by the interaction between genotypes and environments over two years.

\begin{tabular}{|c|c|c|c|c|c|c|}
\hline \multirow[t]{2}{*}{ Genotype } & \multicolumn{2}{|c|}{$\begin{array}{c}\text { number of panicles } \\
\text { plant }^{-1}\end{array}$} & \multicolumn{2}{|c|}{ Sterility (\%) } & \multicolumn{2}{|c|}{$\begin{array}{l}\text { 100-grain weight } \\
\text { (g) }\end{array}$} \\
\hline & NS & DS & NS & DS & NS & DS \\
\hline Giza 159 & $22.05 \mathrm{cde}$ & $13.93 \mathrm{t}-\mathrm{w}$ & $7.29 \mathrm{opq}$ & $17.07 b c$ & $2.51 \mathrm{f}-\mathrm{j}$ & $2.22 \mathrm{no}$ \\
\hline Giza175 & $18.77 \mathrm{j}-\mathrm{m}$ & $13.53 \mathrm{uvw}$ & $6.92 \mathrm{p}-\mathrm{s}$ & $17.23 b$ & $2.32 \mathrm{j}-\mathrm{o}$ & $2.01 \mathrm{p}$ \\
\hline Giza 176 & $18.95 \mathrm{i}-\mathrm{m}$ & $13.10 \mathrm{vw}$ & $10.60 \mathrm{kl}$ & $20.67 \mathrm{a}$ & $2.52 \mathrm{e}-\mathrm{j}$ & $1.71 \mathrm{q}$ \\
\hline Giza 177 & $19.67 \mathrm{~g}-\mathrm{k}$ & $11.78 x y$ & $7.26 \mathrm{opq}$ & $16.23 \mathrm{~cd}$ & $2.60 \mathrm{c}-\mathrm{h}$ & $2.261-0$ \\
\hline Giza 178 & $23.53 \mathrm{ab}$ & $18.58 \mathrm{klm}$ & $7.10 \mathrm{opq}$ & $11.53 \mathrm{ij}$ & $2.32 \mathrm{j}-\mathrm{o}$ & $2.25 \mathrm{mno}$ \\
\hline Sakha 101 & $20.52 \mathrm{fgh}$ & $13.07 \mathrm{vw}$ & 7.66opq & $16.22 \mathrm{~cd}$ & $2.53 \mathrm{e}-\mathrm{i}$ & $2.40 \mathrm{i}-\mathrm{n}$ \\
\hline Sakha 102 & $18.53 \mathrm{k}-\mathrm{n}$ & $14.85 \mathrm{tu}$ & 7.12opq & $15.43 d$ & $2.56 \mathrm{~d}-\mathrm{i}$ & 2.18 op \\
\hline Sakha 103 & $19.61 \mathrm{~g}-\mathrm{k}$ & $11.27 \mathrm{y}$ & $9.02 n$ & $17.46 \mathrm{~b}$ & $2.42 \mathrm{~h}-\mathrm{m}$ & $2.01 \mathrm{p}$ \\
\hline Sakha 104 & $21.13 \mathrm{def}$ & $17.53 \mathrm{~m}-\mathrm{r}$ & 7.72opq & $15.28 \mathrm{de}$ & $2.66 \mathrm{c}-\mathrm{g}$ & $2.43 \mathrm{~h}-\mathrm{m}$ \\
\hline GZ1368-S-5-4 & $23.73 a$ & $19.02 \mathrm{i}-1$ & $5.77 \mathrm{t}$ & $11.28 \mathrm{jk}$ & $2.52 \mathrm{e}-\mathrm{j}$ & $2.32 \mathrm{j}-\mathrm{o}$ \\
\hline GZ 5121-5-2 & $21.19 \mathrm{def}$ & $18.46 \mathrm{k}-\mathrm{n}$ & $6.03 \mathrm{st}$ & $12.22 \mathrm{~g}-\mathrm{j}$ & $2.49 \mathrm{~g}-\mathrm{k}$ & $2.51 \mathrm{f}-\mathrm{j}$ \\
\hline Giza 182 & $22.85 \mathrm{abc}$ & 17.711-p & 7.960 & $14.50 \mathrm{e}$ & $2.51 \mathrm{f}-\mathrm{j}$ & $2.25 \mathrm{mno}$ \\
\hline Agmi & $20.45 f g h$ & $12.80 w x$ & 6.13 rst & $12.24 \mathrm{~g}-\mathrm{j}$ & $2.42 \mathrm{~h}-\mathrm{m}$ & $2.30 \mathrm{k}-\mathrm{o}$ \\
\hline Goari & $20.36 f-i$ & $18.24 \mathrm{k}-\mathrm{o}$ & $7.87 \mathrm{opq}$ & $15.71 \mathrm{~d}$ & $2.70 \mathrm{c}-\mathrm{f}$ & 2.40h-n \\
\hline Nabatat Asmar & $18.27 \mathrm{k}-\mathrm{o}$ & $16.64 \mathrm{pqr}$ & 11.75hij & $12.52 \mathrm{fgh}$ & $2.48 \mathrm{~g}-\mathrm{k}$ & $2.40 \mathrm{~h}-\mathrm{n}$ \\
\hline IRAT 170 & $16.93 \mathrm{o}-\mathrm{r}$ & $15.18 \mathrm{st}$ & $9.01 \mathrm{n}$ & $12.49 \mathrm{f}-\mathrm{i}$ & $2.55 \mathrm{e}-\mathrm{i}$ & $2.43 \mathrm{~h}-\mathrm{m}$ \\
\hline IRAT 112 & 17.16n-r & $14.67 \mathrm{tu}$ & $11.35 \mathrm{jk}$ & $12.19 \mathrm{~g}-\mathrm{j}$ & $2.53 \mathrm{e}-\mathrm{i}$ & $2.15 o p$ \\
\hline Milyang 93 & $17.661-q$ & $14.16 \mathrm{t}-\mathrm{w}$ & $7.02 \mathrm{o}-\mathrm{r}$ & $13.41 \mathrm{f}$ & $2.67 \mathrm{c}-\mathrm{g}$ & $1.83 q$ \\
\hline IET 1444 & $18.25 \mathrm{k}-\mathrm{o}$ & $19.20 \mathrm{~h}-\mathrm{k}$ & 7.36opq & 11.63hij & 2.46h-1 & $2.40 \mathrm{i}-\mathrm{n}$ \\
\hline Suweon 360 & $20.08 \mathrm{f}-\mathrm{j}$ & $16.17 \mathrm{rs}$ & 7.64opq & $12.94 \mathrm{fg}$ & $2.24 \mathrm{mno}$ & $2.14 \mathrm{op}$ \\
\hline Yun Len 4 & $18.73 \mathrm{j}-\mathrm{m}$ & $15.16 \mathrm{st}$ & 7.90op & $11.33 \mathrm{jk}$ & $2.74 \mathrm{bcd}$ & $2.65 \mathrm{c}-\mathrm{g}$ \\
\hline WAB 878 & $22.40 \mathrm{bcd}$ & $16.75 \mathrm{pqr}$ & 7.38opq & $9.09 \mathrm{n}$ & $2.89 \mathrm{~b}$ & 2.71cde \\
\hline Morobrekan & $19.25 \mathrm{~h}-\mathrm{k}$ & $16.960-r$ & 7.78opq & $10.211 \mathrm{~m}$ & $3.57 \mathrm{a}$ & $2.76 \mathrm{bc}$ \\
\hline Suweon 349 & $20.09 f-j$ & $16.27 \mathrm{qrs}$ & $6.87 \mathrm{qrs}$ & $13.08 \mathrm{fg}$ & $2.43 \mathrm{~h}-\mathrm{m}$ & $2.24 \mathrm{mno}$ \\
\hline E. yasmine & 20.97efg & 14.32tuv & $9.49 \mathrm{mn}$ & $15.90 \mathrm{~d}$ & $2.56 \mathrm{~d}-\mathrm{i}$ & $2.50 \mathrm{~g}-\mathrm{k}$ \\
\hline
\end{tabular}

Means followed by a common letter are not significantly different at the $5 \%$ level by DMRT.

$\mathrm{NS}=$ continues flooding and $\mathrm{DS}=$ irrigation every 12 days

Egypt. J. Agron. 37, No. 1 (2015) 
Highest sterility percentage (\%) was observed under drought conditions compared with the non-stress conditions in all of the studied rice genotypes and the lowest sterility percentages was recorded by the Morobrekan, WAB 878 and GZ 1368-S-5-4. in Table 2. Changes in carbohydrate levels and enzyme activities, associated with inhibition of starch accumulation in pollen, are potential causes of spikelet sterility (Sheoran \& Saini, 1996) spikelet sterility also found affected by a slower rate of panicle exertion due to water stress (O’Toole \& Namuco, 1983).

With regard to 100-grain weight (g) in Table 2, the cultivars Morobrekan, WAB 878 and Yun Len 4 gave the highest mean values under the normal and drought conditions compared while the Suweon 360 under normal condition and Giza 176 under drought conditions were given the lowest mean values. In general, there was a significant reduction in 100-grain weight (g) under drought stress comparing with normal condition in most of the studied rice varieties, Water stress imposed during the grain filling period enhanced remobilization of pre-stored carbon reserves to grains and accelerated grain filling and this led to reduction in 100-grain weight (g) under drought conditions (Yang et al., 2001).

Table 3 shows significantly difference on number of panicles plant ${ }^{-1}$, sterility $(\%)$ and 100-grain weight $(\mathrm{g})$ as affected by the interaction between genotypes and environments over two years.

The genotypes GZ 5121-5-2, Sakha 101and Giza 178 had the highest grain yield plant $^{-1}(\mathrm{~g})$ under normal conditions (43.1, 44.50 and 45.66) while the genotypes GZ 1368-S-5-4, Morobrekan, GZ 5121-5-2, WAB 878 and Goari had the highest grain yield plant $^{-1}(\mathrm{~g})$ under drought conditions $(31.38,30.98,29.73$, 28.99 and 29.25) in Table 3. The outstanding performance of in GZ 1368-S-5-4 for grain yield plant ${ }^{-1}(\mathrm{~g})$ under drought conditions seems due to its superiority for number of panicles plant ${ }^{-1}$, heavier grain weight and low sterility percentage $(\%)$.

Table 3 shows that the highest water use efficiency WUE was recorded in the Giza 178, Sakha 101 and GZ 5121-5-2 cultivars under the normal conditions and in the GZ 1368-S-5-4, Morobrekan and GZ 5121-5-2 cultivars under the drought conditions. These results are in accordance with those obtained by $\mathrm{Yu}$ et al. (2003) and Cha-um et al. (2010).

Harvest index, another important physiological parameter, were calculated as highest in the Gaori and IRAT 112 (29.8 and 27.8 \%) cultivars under the drought conditions, respectively in Table 3. Contrarily, the lowest harvest index values were detected in the Giza 177 and Sakha 104 (45.9 and 42.7) under non-stress conditions, respectively. In general, the highest harvest index values were observed under non-stress condition compared with that under drought condition in all of the studied rice genotypes. This finding could be attributed to the adversely effect of water stress on the grain yield and straw weight of plant and these could be reduced by the harvest index. This result is consistent with the findings of Keshava et al. (2011) and Abdel - Hafez et al. (2013). 
TABLE 3. Grain yield $\operatorname{plant}^{-1}(\mathrm{~g})$, water use efficiency and harvest index (\%) as affected by the interaction between genotypes and environments over two years.

\begin{tabular}{|c|c|c|c|c|c|c|}
\hline \multirow[t]{2}{*}{ Genotype } & \multicolumn{2}{|c|}{ 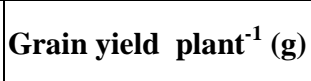 } & \multicolumn{2}{|c|}{$\begin{array}{c}\text { Water use efficiency } \\
\text { (WUE) }\end{array}$} & \multicolumn{2}{|c|}{$\begin{array}{c}\text { Harvest index } \\
(\%)\end{array}$} \\
\hline & NS & DS & NS & DS & NS & DS \\
\hline Giza 159 & 28.39no & $24.87 \mathrm{bq}$ & $0.49 \mathrm{qrs}$ & $0.62 \mathrm{i}-1$ & 28.43opq & $25.56 \mathrm{r}$ \\
\hline Giza175 & $38.40 \mathrm{fg}$ & $19.22 \mathrm{u}$ & $0.66 \mathrm{ghi}$ & $0.48 \mathrm{rs}$ & $32.20 \mathrm{j}-\mathrm{n}$ & $22.27 \mathrm{st}$ \\
\hline Giza 176 & $42.22 \mathrm{c}$ & $19.50 \mathrm{tu}$ & $0.73 c-f$ & $0.49 \mathrm{qrs}$ & $30.151-p$ & $15.73 y z$ \\
\hline Giza 177 & $41.90 \mathrm{~cd}$ & $20.00 \mathrm{stu}$ & $0.72 \mathrm{def}$ & $0.50 \mathrm{o}-\mathrm{s}$ & $45.94 \mathrm{a}$ & $27.66 \mathrm{qr}$ \\
\hline Giza 178 & $45.66 \mathrm{a}$ & 27.580 & $0.79 \mathrm{a}$ & $0.69 \mathrm{fg}$ & $38.05 \mathrm{de}$ & $23.31 \mathrm{~s}$ \\
\hline Sakha 101 & $44.50 \mathrm{ab}$ & $21.58 \mathrm{r}$ & $0.77 \mathrm{abc}$ & $0.54 \mathrm{no}$ & $40.63 b c$ & $12.92 \mathrm{z}$ \\
\hline Sakha 102 & $40.53 \mathrm{de}$ & $21.16 \mathrm{rs}$ & $0.70 \mathrm{efg}$ & $0.53 n-q$ & $37.36 \mathrm{ef}$ & $23.34 \mathrm{~s}$ \\
\hline Sakha 103 & $42.41 \mathrm{c}$ & $21.74 \mathrm{r}$ & $0.73 \mathrm{c}-\mathrm{f}$ & $0.54 n$ & $39.86 \mathrm{~cd}$ & $17.67 x y$ \\
\hline Sakha 104 & $42.80 \mathrm{c}$ & $22.38 \mathrm{r}$ & $0.74 b-e$ & $0.56 \mathrm{mn}$ & $42.70 \mathrm{~b}$ & $15.80 \mathrm{yz}$ \\
\hline GZ 1368-S-5-4 & $40.24 \mathrm{e}$ & $31.38 \mathrm{k}$ & $0.69 f g$ & $0.79 a$ & $36.50 \mathrm{ef}$ & $19.19 u-x$ \\
\hline GZ 5121-5-2 & $43.18 b c$ & $29.731 \mathrm{mn}$ & $0.75 \mathrm{bcd}$ & $0.74 \mathrm{bcd}$ & 36.19efg & $21.12 \mathrm{~s}-\mathrm{v}$ \\
\hline Giza 182 & $37.29 \mathrm{gh}$ & $18.57 \mathrm{u}$ & 0.64hij & $0.46 \mathrm{~s}$ & $33.74 \mathrm{~h}-\mathrm{k}$ & $15.16 z$ \\
\hline Agmi & $30.32 \mathrm{klm}$ & $21.00 \mathrm{rst}$ & $0.52 \mathrm{n}-\mathrm{r}$ & $0.53 n-q$ & $31.24 \mathrm{k}-\mathrm{n}$ & 17.97wxy \\
\hline Goari & $35.28 \mathrm{ij}$ & $29.25 \mathrm{mn}$ & $0.61 \mathrm{jkl}$ & $0.73 c-f$ & $35.08 \mathrm{f}-\mathrm{i}$ & $29.80 n-q$ \\
\hline Nabatat Asmar & $42.19 \mathrm{c}$ & $19.93 \mathrm{stu}$ & $0.73 c-f$ & $0.50 \mathrm{o}-\mathrm{s}$ & $33.47 \mathrm{ijk}$ & $19.88 \mathrm{t}-\mathrm{x}$ \\
\hline IRAT 170 & $28.94 \mathrm{mno}$ & $23.86 \mathrm{q}$ & $0.50 \mathrm{o}-\mathrm{s}$ & $0.60 \mathrm{klm}$ & $31.29 \mathrm{k}-\mathrm{n}$ & $25.74 \mathrm{r}$ \\
\hline IRAT 112 & $31.24 \mathrm{kl}$ & $25.47 p$ & $0.54 \mathrm{nop}$ & $0.64 \mathrm{ijk}$ & $33.91 \mathrm{~g}-\mathrm{j}$ & $27.83 \mathrm{pqr}$ \\
\hline Milyang 93 & $31.66 \mathrm{k}$ & $24.80 \mathrm{pq}$ & $0.55 n$ & $0.62 \mathrm{i}-1$ & $36.51 \mathrm{ef}$ & $27.67 \mathrm{qr}$ \\
\hline IET 1444 & $38.37 \mathrm{fg}$ & $25.33 \mathrm{pq}$ & 0.66ghi & $0.63 \mathrm{ijk}$ & $30.11 \mathrm{~m}-\mathrm{p}$ & $20.20 \mathrm{t}-\mathrm{w}$ \\
\hline Suweon 360 & $35.35 \mathrm{ij}$ & $25.19 \mathrm{pq}$ & $0.61 \mathrm{jkl}$ & $0.63 \mathrm{i}-1$ & $31.46 \mathrm{j}-\mathrm{n}$ & 20.56tuv \\
\hline Yun Len 4 & 28.61no & $25.67 p$ & $0.49 \mathrm{qrs}$ & 0.64hij & $32.69 \mathrm{i}-1$ & $21.23 \mathrm{~s}-\mathrm{v}$ \\
\hline WAB 878 & 36.28hi & $28.99 \mathrm{mno}$ & $0.63 \mathrm{i}-1$ & $0.73 c-f$ & 30.691-o & $27.61 \mathrm{qr}$ \\
\hline Morobrekan & $39.46 \mathrm{ef}$ & $30.98 \mathrm{kl}$ & $0.68 \mathrm{gh}$ & $0.78 \mathrm{ab}$ & $35.92 \mathrm{e}-\mathrm{h}$ & $18.71 \mathrm{vwx}$ \\
\hline Suweon 349 & $34.14 j$ & $25.46 \mathrm{p}$ & $0.591 \mathrm{~m}$ & $0.64 \mathrm{ijk}$ & $32.43 \mathrm{j}-\mathrm{m}$ & $21.40 \mathrm{stu}$ \\
\hline E. yasmine & $36.62 \mathrm{hi}$ & $19.88 \mathrm{stu}$ & $0.63 \mathrm{ijk}$ & $0.50 \mathrm{p}-\mathrm{s}$ & $37.63 \mathrm{de}$ & $21.05 \mathrm{~s}-\mathrm{v}$ \\
\hline
\end{tabular}

Means followed by a common letter are not significantly different at the 5\% level by DMRT. $\mathrm{NS}=$ continues flooding and DS= irrigation every 12 days

\section{Genetic parameters}

Estimates of genetic variance $(\mathrm{GV})$, phenotypic variance (PV), genotypic coefficient of variability (GCV), phenotypic coefficient of variability (PCV) and heritability (HB) for all the studied characters are given in Table 4. Results showed that the grain yield plant $^{-1}(\mathrm{~g})$ and harvest index had the highest genotypic and phenotypic variances, while WUE (unit) recorded the lowest genotypic and phenotypic variances under both normal and drought conditions.

Egypt. J. Agron. 37, No. 1 (2015) 
TABLE 4. Estimates of phenotypic variance (PV), genetic variance $(\mathrm{GV})$, genetic coefficient of variance (GCV), phenotypic coefficient of variance (PCV) and heritability in broad sense $(\mathrm{H})$ for all the studied traits.

\begin{tabular}{|l|c|c|c|c|c|c|c|c|c|c|}
\hline \multirow{2}{*}{ Characters } & \multicolumn{2}{|c|}{ GV } & \multicolumn{2}{|c|}{ PV } & \multicolumn{2}{|c|}{$\begin{array}{c}\text { GCV } \\
(\%)\end{array}$} & \multicolumn{2}{c|}{$\begin{array}{c}\text { PCV } \\
(\%)\end{array}$} & \multicolumn{2}{|c|}{$\begin{array}{c}\text { HB } \\
(\%)\end{array}$} \\
\cline { 2 - 11 } & NS & DS & NS & DS & NS & DS & NS & DS & NS & DS \\
\hline number of panicles plant $^{-1}$ & 3.42 & 5.16 & 4.24 & 5.70 & 9.25 & 14.59 & 10.30 & 15.33 & 90.58 & 80.65 \\
\hline Sterility percentage (\%) & 2.25 & 7.25 & 2.46 & 7.70 & 18.93 & 19.34 & 19.82 & 19.94 & 94.07 & 91.24 \\
\hline 100-grain weight (g) & 0.06 & 0.06 & 0.07 & 0.07 & 9.48 & 10.41 & 10.25 & 11.61 & 85.58 & 80.37 \\
\hline Grain yield plant ${ }^{-1}(\mathrm{~g})$ & 27.52 & 14.91 & 28.55 & 15.84 & 14.01 & 15.99 & 14.27 & 16.49 & 96.40 & 94.09 \\
\hline Water use efficiency & 0.008 & 0.01 & 0.009 & 0.01 & 13.87 & 15.99 & 14.71 & 16.83 & 90.32 & 88.89 \\
\hline Harvest index (\%) & 13.47 & 19.73 & 25.92 & 21.73 & 10.40 & 20.59 & 14.42 & 21.60 & 90.81 & 51.7 \\
\hline $\begin{array}{l}\text { GV=genotypic variance, PV= phenotypic variance, GCV= genetic coefficient of variation, PCV= } \\
\text { phenotypic coefficient of variation and HB= heritability in broad sense }\end{array}$
\end{tabular}

Relatively, high phenotypic coefficient of variability (PCV) was found for the harvest index (21.60) and sterility percentage (19.94) under drought stress while, it was lower for 100-grain weight (g) (10.25 g) under normal condition.

The genotypic coefficient of variability (GCV) showed the same trend as for PCV for these traits, indicating that these two traits might be more genotypically predominant, and it would be possible to achieve further improvement in both traits. The genetic coefficient of variability refers to the additive and nonadditive genetic variance played an important role in inheritance of these traits. These results are in agreement with those obtained by Abd Allah et al (2005), El-Malky et al (2008), and Hammoud et al. (2012).

High estimates of heritability (\%) were found in all characters under both normal and drought conditions, which ascertains the presence of both additive and non-additive genetic variance in the inheritance of most traits except harvest index under drought stress $(51.7 \%)$. Therefore, it could be concluded that its selection procedures are successful in improving these traits we investigated. Similar results were obtained by Abd Allah et al. (2005), Hammoud et al. (2012) and Abdel- Hafez et al. (2013) and these researchers are verified the our findings.

Correlation coefficients among the studied traits under normal and drought conditions over the two years are seen in Table 5. Under normal environment grain yield was significantly and positively correlated with WUE and harvest index. Also positive and significant correlation was observed between WUE and harvest index. Similar positive correlation was reported by Hadifa (2012).

Positive correlation between grain yield and WUE cleared that high WUE cultivars can lead to genotypes with high yield potential (Eivazi \& Habibi, 
2013). Under the drought stressed environs, grain yield was significantly and positively correlated with harvest index, number of panicles plant ${ }^{-1}$ and 100grain weight $(\mathrm{g})$, this show that increasing the number of panicles plant ${ }^{-1}$ and 100- grain weight $(\mathrm{g})$ will consequently increase the grain yield plant $^{-1}(\mathrm{~g})$. Significant positive correlation between grain yield with the number of panicles plant $^{-1}$ and 100- grain weight (g) under stress was also observed by Gomez et al. (2006) and Site Noorzuraini et al. (2012).

TABLE 5. Correlation coefficients among the studied traits under normal and drought stress over the two years.

\begin{tabular}{|l|c|c|c|c|c|c|}
\hline \multirow{2}{*}{ Character } & Env. & W.U.E. & $\begin{array}{c}\text { Harvest } \\
\text { index (\%) }\end{array}$ & $\begin{array}{c}\text { Number of } \\
\text { panicles } \\
\text { plant }^{-1}\end{array}$ & $\begin{array}{c}\text { Sterility } \\
(\%)\end{array}$ & $\begin{array}{c}\text { 100 grain } \\
\text { weight } \\
\text { (g) }\end{array}$ \\
\hline \multirow{2}{*}{$\begin{array}{l}\text { Grain yield } \\
\text { plant }^{-1}(\mathrm{~g})\end{array}$} & Normal & $0.99^{* *}$ & $0.585^{* *}$ & 0.302 & -0.003 & 0.196 \\
\cline { 2 - 7 } & Drought & $0.99^{* *}$ & 0.331 & $-.613^{* *}$ & $-0.645^{* *}$ & $0.451^{*}$ \\
\hline \multirow{2}{*}{ W.U.E. } & Normal & & $0.585^{* *}$ & 0.301 & -0.003 & 0.196 \\
\cline { 2 - 7 } & Drought & & 0.330 & $0.613^{* *}$ & $-0.645^{* *}$ & $0.452^{*}$ \\
\hline \multirow{2}{*}{$\begin{array}{l}\text { Harvest index } \\
\text { (\%) }\end{array}$} & Normal & & & 0.137 & -0.105 & 0.212 \\
\cline { 2 - 7 } panicles plant $^{-1}$ & Drought & & & 0.014 & -0.208 & 0.019 \\
\cline { 2 - 7 } & Drought & & & & $-0.581^{* *}$ & $0.444^{*}$ \\
\hline \multirow{2}{*}{ Sterility (\%) } & Normal & & & & & -0.088 \\
\cline { 2 - 7 } & Drought & & & & & $-0.634^{* *}$ \\
\hline
\end{tabular}

Env. =environments and WUE $=$ water use efficiency

Positive and significant correlation was obtained between WUE and number of panicles plant ${ }^{-1}$ and 100-grain weight $(\mathrm{g})$. Also, it was significantly correlated with number of panicle plant ${ }^{-1}$. These traits appeared to be promising traits for selection to improve the yield under stress and consequently develop high yielding drought tolerant rice varieties. All traits studied except harvest index had significant and negative correlation with sterility percentage (\%), indicating that the increasing of sterility percentage led to decrease grain yield. Hadifa (2012) reported negative correlation between sterility percentage and grain yield under water stress condition.

\section{References}

Abd Allah, A.A., Waled, M.E., Okasha, E.M. and Alaa, Z.E. (2009) Rationalization of irrigation water use in some rice cultivars using different planting methods in North Delta, Egypt. J. Plant \& Environ. Sci. 2,79-85.

Egypt. J. Agron. 37, No. 1 (2015) 
Abd Allah, A.A., Gorgy, R.N. and Zayed, B.A. (2005) Screening some rice genotypes (Oryza sativa L.) under drought conditions. J. Agric. Res., Tanta Univ. 31(2), 244258.

Abd Allah, A.A. (2010) Development of some high yielding rice lines tolerant to drought conditions. J. Medi. Plants Res. 4 (7), 528-535.

Abdel - Hafez, A.G., Abd Allah, A.A., EL Degwy, I.S. and Ghazy, M.I. (2013) Grow characters and yield response of rice genotypes to high temperature and water deficit. The $8^{\text {th }}$ Plant Breed. Int. Conf. 14-15 May 2013. Egypt J. Plant Breed. 17(2), 14-130 (Special Issue).

Bartlett, M.S. (1937) Properties in sufficiency and statistical tests. Proc. Roy. Soc., 160 (1), pp. 268-282.

Bouman, B.A.M, Peng, S., Castaòed, A.R. and Visperas, R.M. (2005) Yield and water use of irrigated tropical aerobic rice systems. Agricultural Water Management, 74(2), 87-105.

Burton, G.W. (1952) Quantitative inheritance in grasses. Proc. $6^{\text {th }}$ Int. Grassland Cong., 1, 277-283.

Cha-um, S., Yooyongwech, S. and Supaibulwatana, K. (2010) Water deficit stress in the reproductive stage of four indica rice (Oryza sativa L.) genotypes. Pak. J. Botany, 52 (5), 3387-3398.

Duncan, D.B. (1955) Multiple Range and Multiple F-tests. Biometrics, 1,1-42.

Eivazi, A. and Habibi, F. (2013) Water use efficiency variation and its components in wheat cultivars. American J. Exp. Agric. 3 (4), 718-730.

El-Malky, M.M., El-Habashy, M.M. and Abdelkhalik, A.F. (2008) Rice germplasm evaluation for agronomic traits and their influence on stem borer (Chilo agamemnon Bles.) resistance. J. Agric. Res., Punjab, Labore- Pakistan 2008, 46 (3), 203-213.

FAO (2013) FAO Stat-Agriculture. Food and Agriculture Organization of the United Nations. Available at http:// faostat.fao. org/site/567/ Desktop Default.aspx? PageID =567\#ancor

Gomez, K.A. and Gomez, A.A. (1984) "Statistical Procedures for Agricultural Research". $2^{\text {nd }}$ ed., Jahn Wiley Sons, New York, USA. 
Gomez, S.M, Kumar, S.S, Jeyaprakash, P., Suresh, R., Biji, K.R., Boopathi, N.M., Price, A.H. and Babu, R.C. (2006) Mapping QTLs linked to physio-morphological and plant production traits under drought stress in rice (Oryza sativa $\mathrm{L}$.) in the target environment. American J. Biochem. Biotech. 2 (4), 161 - 169.

Hadifa, A.A. (2012) The role of root and shoot characteristics in rice drought tolerance. Ph. D. Thesis, Fac. Agric., Kafrelshiekh Univ. Egypt.

Hammoud, S.A.A., Sedeek, S.E.M., Rewaniy, I.O.A. and El-Namaky, R.A. (2012) Genetic behavior of some agronomic traits, blast disease and stem borer resistance in two Nlevels. J. Agric. Res., Kafrelsheikh. Univ. 38 (1), 83-105.

Hansen, C.H., Robinson, H.P., and Comstock, R.E. (1956) Biometrical studies of yield in segregating populations of Korean Lespedeza. Agron. J. 48, 268-272.

Hansen, J.M., Go, Y.M. and Jones, D.P. (2006) Nuclear and Mitochondrial compartmentation of oxidative stress and redox signaling. Ann. Rev. Pharmacol. Toxicol. 46, 215-234.

Ji, X.M., Raveendran, M., Oane, R., Ismail, A., Lafitte, R., Bruskiewich, R., Cheng, S.H. and Bennett, J. (2005) Tissue- specific expression and drought responsiveness of cell-wall inverts genes of rice at flowering. Plant Mol. Biol. 59 (6), 945-964.

Jongdee, B., Pantuwan, G., Fukai, S. and Fischer, K. (2002) Improving drought tolerance in rainfed lowland rice: an example from Thailand. Agric. Water Manag. 80, 225-40.

Keshava, M.B.C., Kumar, A. and Hittalmani, S. (2011) Response of rice (Oryza sativa L.) genotypes under aerobic conditions. Electronic J. Plant Breed, 2 (2), 194-199.

Krishnan, P., Ramakrishnan, B., Reddy, K.R. and Reddy, V.R. (2011) Hightemperature effects on rice growth, yield, and grain quality. Advances in Agron. 111, 87-206.

Liu, J.X., Liao, D.Q., Oane, R., Estenor, L., Yang, X.E., Li., Z.C. and Bennet, J. (2006) Genetic variation in the sensitivity of anther dehiscence to drought stress in rice. Field Crop Res. 97, 87-100.

O'Toole, J.C. and Namuco, O.S. (1983) Role of panicle exertion in water stress plant growth processes. American Society of Agronomy/Crop Science Society of America/Soil Science Society of America, Madison, WI, p. 301-356

Egypt. J. Agron. 37, No. 1 (2015) 
Pantuwan, G., Fukai, S., Cooper, M., Rajatasereekul, S. and O'Toole, J.C. (2002) Yield response of rice (Oryza sativa L.) genotypes to different types of drought under rainfed lowlands Part 3. Plant factors contributing to drought resistance. Field Crops Res., 73, 181-200.

Prasad, P.V.V., Staggenborg, S.A. and Ristic, Z. (2008) Impacts of drought and/or heat stress on physiological, developmental, growth and yield processes of crop plants. In: "Response of Crops to Limited Water: Understanding and Modeling Water Stress Effects on Plant Growth Processes", Ahuja, L.H., Saseendran, S.A., (Ed)., Advances in Agricultural Systems Modeling Series 1, ASA-CSSA: Madison, WI, USA, pp. 301-355.

Sheoran, I.S. and Saini, H.S. (1996) Drought - induced male sterility in rice: changes in carbohydrate levels and enzyme activities associated with the inhibition of starch accumulation in pollen. Sexual Plant Reproduction, 9, 161-169.

Singh, S., Aggarwal, P.K. and Yadav, R.N. (2010) Growth and yield response of rice under heat stress during vegetative, reproductive, and ripening growth phases. International Rice Research Notes, (0117-4185), 35, 1-4.

Site Noorzuraini, A.R., Borromeo, T.H., Altoveros, N.C. and Kumar, A. (2012) Growth performance of selected Malaysian rice germplasm under drought stress environment. J. Trop. Agric. Fd. Sc. 40 (2), 169-179

Yang, J., Zhang, J., Wang, Z., Zhu, Q. and Wang, W. (2001) Remobilization of carbon reserves in response to water deficit during grain filling of rice. Field Crop. Res., 71, 47-55.

Yu, J.Q., Nan, O.Y., Miao, Y.S., Hai, X.D. and Ping, Z.G. (2003) Influence of soil drought stress on leaf rolling index in different rice varieties. Chin. J. Rice Sci. 17(4), 349-354. 


\section{تأثير نقص ماء التربه على المحصول ومكوناته فى مراحل النمو

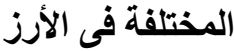

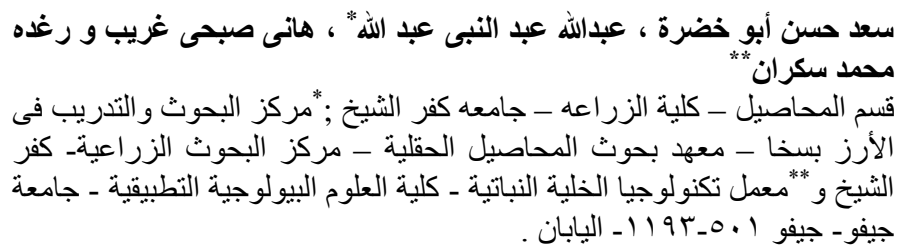

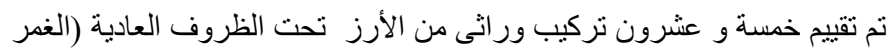

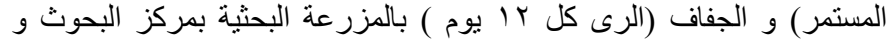

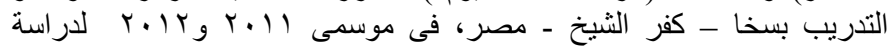

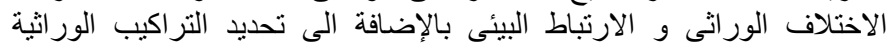

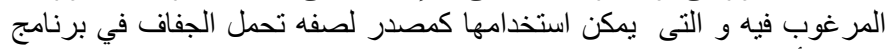
تربية الأرز.

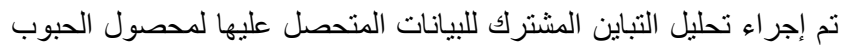

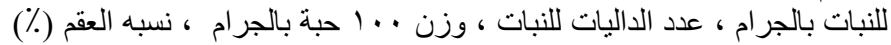

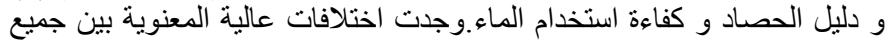

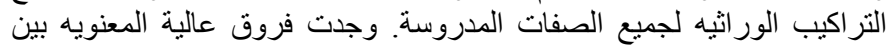
منوسطات مربعات التفاعل بين التر اكيب الور الثيه و البيئه لكل الصفات فالته المدروسة.

GZ Morobrekan, GZ 1368-S-5-4 واتلت التراكيب الوراثيه GAB 878, 5121-5-2,

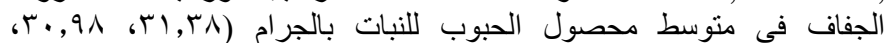

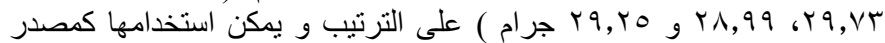
لتحسين صفه محصول الحبوب تحت ظروف تحمل الجفاف .

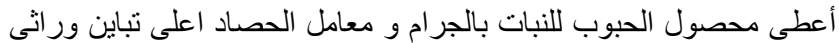

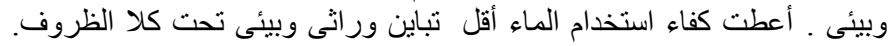

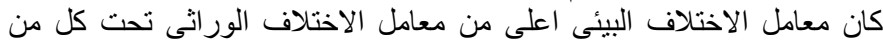

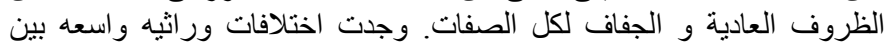

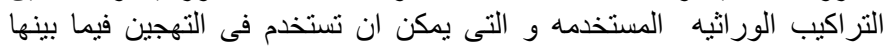

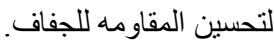

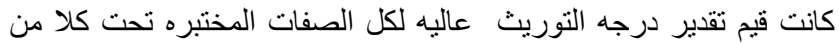

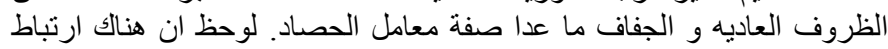

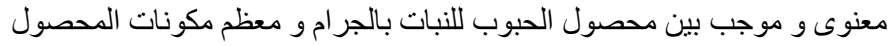
تحت الظروف العادية و الجفاف. 